presence of normal rabbit serum; (b) immediately after the introduction of uræmic serum; (c) after about $20 \mathrm{hr}$. in contact with uræmic serum.

This procedure was carried out on four occasions, using one or other of the two samples of uræmic serum and explants of spleen from three different normal rabbits.

When the film obtained from each of these experiments was examined, it was seen that the introduction of uræmic serum produced no detectable changes in either the activity or the morphology of the lymphocytes and mecrophages. Furthermore, these cells continued to behave normally, with the macrophages exhibiting active pinocytosis, after periods of up to $24 \mathrm{hr}$. continuous immersion in uræmic serum.

Recent work suggests that the prolonged survival of skin homografts in uræmic recipients may possibly be due to impairment of the metabolism of the antibody-forming cells of lymphoid tissue ${ }^{3}$. Of the various cell types which exist in lymphoid tissue, the present experiments were concerned only with the macrophages and lymphocytes, as these are the predominant cells present in the outgrowths from explants of spleen. The extent to which these particular cell types play a part in the homograft reaction is not precisely known ; but there is a certain amount of evidence $e^{6-8}$ to support the suggestion that macrophages and lymphocytes may be concerned in the carly stages of antibody formation.

The experiments described here seem to indicate that the delay in the rejection of skin homografts in uræmic animals is not a result of interference with the motility of macrophages and lymphocytes, nor due to impairment of the ability of macrophages to ingest material by pinocytosis. Further, any abnormality of metabolism induced in these cells by uræmic serum is not reflected by detectable changes in their appearance or behaviour as seen under phase-contrast microscopy.

Departments of Anatomy and Surgery,

$$
\text { J. A. Sharp }
$$

F. G. SMIDDY

University of Leeds.

'Smiddy, F. G., Burwell, R. G., and Parsons, H. M., Brit. J. Surg., 48, 328 (1960).

${ }^{2}$ Couch, N. P., et al., Surg. Forum, 7, 626 (1957).

${ }^{3}$ Burwell, R. G., Smiddy, F. G., and Parsons, F. M., Brit. J. Surg. (in the press).

4Archibald, R. M., J. Biol. Chem., 15\%, 507 (1945).

'Sharp, J. A., Exp. Cell Res., 17, 519 (1959).

- Roberts, J. A., et al., Arch. P'athol., 64, 324 (1957).

' Fishman, M., Nature, 183, 1200 (1959).

8 Sharp, J. A., and Burwell, R. G., Nature, 188, 474 (1960).

\section{Electron-microscopic Studies of the Acidophil Cells in the Gills and Pseudo- branchs of Fish}

A CHLORIDE secretory function for the adidophil cells in the pseudobranch of fishes has been disclaimed ${ }^{1,2}$. If theso cells in the gills of fish are regarded es ion-regulatory it becomes important to establish whether the cells of gills and pseudobranch are the same. The morphological and staining properties, as seen under the light microscope, suggested that they were very similar. Recently, a number of papers have been published deseribing the electron-microscopic struction of the acidophil cells in the gills ${ }^{3-5}$ and the psoudobranch ${ }^{6}$. Comparisons of the photographs and their descriptions in these publications is again suggestive that the cells in both areas may be identical.
Although many of the descriptions published were of cells in the gills or pseudobranchs from the same species, kept in identical conditions, none compared gill and pseudobranch colls in the same fish. We have made this comparison in the flounder (Pleuronectes flesus), and the cells are characteristic and identical in appearance in both sites and very strongly resemble the descriptions given by other authors. Cells similar to those found in the gills and pseudobranchs of teleosts are reported in the gills of two species of elasmobranchs (Urobatis and Squalus) ${ }^{5}$, adding support to the view that they are not ion regulatory.

Studies of the pseudobranch suggested that it had an endocrine function ${ }^{2}$, related to colour change. Further work has indicated that the changes in colour observed were a reflexion of deeper metabolic changes in the fish. Removal of the pseudobranchs reduces the oxygen uptake by as much as a half and reduces the activity of the fish; such fish survive low concentrations of oxygen lethal to normal fish ${ }^{2}$. The pseudobranoh's close link with the eye suggests that the metabolic changes could be induced by changes in light intensity.

It is suggested that the morphologically identical cells in the gills have a similar endocrine function, although not controlled as in the pseudobranch. It is significant that these cells were first described, and found in largest numbers, in the gills of the $\mathrm{eel}^{7}$, a fish lacking a pseudobranch.

If the cell function is linked to the metabolism of the fish, then the cytological changes described within them when fish are transferred to different salinities may be related to the metabolic changes in the fish as it undergoes the stresses of osmotic adaptation. A similar explanation could be given for the changes in the numbers of these cells on the gills of migrating species 8 .

We wish to thank Dr. J. MacKenzie, Anatomy Department, University of Aberdeen, and Mr. W. Hodgkiss, Torry Research Station, Aberdeen, for help with the electron microscope preparations.

\section{F. G. T. HoLLIDAY}

Natural History Dopartment, Marischal College, University of Aberdeen.

\section{GWYNeth ParRy}

Ministry of Agriculture, Fisheries and Food,

Freshwater Fisheries Laboratory, London, S.W.1.

Parry, G., Holliday, F. G. T., and Blaxter, J. H. S., Nature, 183 , 1248 (1059).

2 Parry, G., and Holliday, F. G. T., J. Exp. Biol., 37, 344 (1960).

${ }^{3}$ Kessel, R. G., and Beams, H. W., Biol. Bull. Woods Hole, 118, 322 (1960).

"Threadgold, L. T., and Houston, A. H., Nature, 190, 612 (1961).

- Doyle, W. L., and Goreeki, D., Physiol. Zool., 34, 81 (1961).

'Copeland, D. E., and Dalton, A. J., J. Biophys. and Biochem. Cytol. $5,393(1959)$.

' Keys, A. B., and Willmer, E. N., J. Physiol., 78, 368 (1932).

Horris, R., J. Exp. Biol., 35, 649 (1958).

\section{Reproductive Structures of Glossopteris angustifolia Bgt.}

Is a collection of plant fossils from Upper Bowen sediments in the Mount Coolon area of Queensland by a field party of the Bureau of Mineral Resources, fertile material of Glossopteris angustifolia Bgt. has been identified. It is of extraordinary botanical interest as it consists of foliage leaves progressively 